OPEN ACCESS

Edited by:

Anna Maria Lavezzi,

University of Milan, Italy

Reviewed by:

Kumar Sannagowdara,

Medical College of Wisconsin, USA

Bülent Eren,

Council of Forensic Medicine of

Turkey, Turkey

*Correspondence:

Riffat Mehboob

mehboob.riffat@gmail.com, riffatmehboob@kemu.edu.pk

Specialty section:

This article was submitted to

Neuropediatrics,

a section of the journal

Frontiers in Neurology

Received: 03 January 2017 Accepted: 24 February 2017

Published: 13 March 2017

Citation:

Mehboob R (2017) Substance P/ Neurokinin 1 and Trigeminal System: A Possible Link to the Pathogenesis

in Sudden Perinatal Deaths.

Front. Neurol. 8:82.

doi: 10.3389/fneur.2017.00082

\section{Substance P/Neurokinin 1 and Trigeminal System: A Possible Link to the Pathogenesis in Sudden Perinatal Deaths}

\author{
Riffat Mehboob* \\ Biomedical Sciences, King Edward Medical University, Lahore, Pakistan
}

Sudden demise of a healthy fetus or a neonate is a very tragic episode in the life of parents. These deaths have been a mystery since ages but still remain unexplained. This review proposes the involvement of trigeminal nerve, neurotransmitter substance $\mathrm{P}(\mathrm{SP})$, and its receptor neurokinin $1(\mathrm{NK}-1 \mathrm{R})$ in regulation of cardiorespiratory control in fetuses and newborns. Anomalies and immaturity of neuroregulatory systems such as trigeminal system in medulla oblongata of brainstem may provide a possible mechanism of sudden perinatal deaths. Vulnerable infants are born with respiratory center immaturity which in combination with any stressor such as cold, hypoxia, and smoking may lead to cessation of breathing and ventilatory response. SP/NK-1R may be involved in regulating the ventilatory control in neonates while it is decreased in fetal and adult life in humans, and any alterations from these may lead to irreversible sleep apnea and fatal breathing, ultimately sudden death. This review summarizes the studies performed to highlight the expression of SP or NK-1R in sudden perinatal deaths and proposes the involvement of trigeminal ganglion along with its nerve and SP/NK-1R expression alteration as one of the possible pathophysiological underlying mechanism. However, further studies are required to explore the role of SP, NK-1R, and trigeminal system in the pathogenesis of sudden infant deaths, sudden intrauterine deaths, stillbirths, and sudden deaths later in human life.

Keywords: sudden infant deaths, sudden perinatal death, substance $P$, neurokinin 1 receptor, trigeminal nerve

\section{INTRODUCTION}

Sudden perinatal deaths comprise of stillbirths, fetal [sudden unexplained intrauterine deaths (SUID)], and infant death [less than 1 year of age, sudden infant deaths (SIDS)] that is spontaneous and mysterious. These cases remain unresolved even after complete autopsy, medical examination, and thorough investigation of death scene (1). Theories on the possible causes of SIDS are more than 100. It is widely accepted that SIDS is a combination of multifactors that occur during the period of increased vulnerability and may cause the fatal outcome in some infant (2). Bergman et al. also suggested that SIDS is not caused by "single characteristic that ordains an infant for death," but depends on an "interaction of risk factors with variable probabilities" (3). Pathophysiology of SIDS remains unexplained (2).

Brainstem anomalies as a possible cause of sudden perinatal death is mostly accepted hypothesis as suggested by Filiano and Kinney (4) in their famous triple risk model. These neuropathologies lead to vulnerable fetus or newborn who becomes unable to respond to any kind of stressor and dies suddenly (5). All the factors whether maternal, infant, environmental, or genetic interfere with 
the cardiorespiratory control leading to final common pathway (death) (6). Mechanisms underlying SIDS appear to originate in fetal period of development resulting in neural damage and affect breathing or blood pressure during sleep later on (5). Neuromodulators like somatostatin, serotonins (7), substance $\mathrm{P}(\mathrm{SP})$, etc. regulate the breathing control activities (8-10). The focus of current review is to highlight the SP and its receptor NK-1R in neuronal respiratory control system during critical ontogenetic periods of human brain development. Our research group for the first time in 2011 (11) suggested the involvement of SP in the pathogenesis of SUID.

\section{SUBSTANCE $P$}

Substance $\mathrm{P}$ is the prototype and first discovered tachykinin. It is a neurotransmitter of the afferent sensory nervous system (12). It is a small peptide hormone consisting of 11 amino acids belonging to tachykinin family (TK) (13). It is the most abundant TK peptide and neurotransmitter in CNS of mammals (14). It has been implicated in various physiological and pathophysiological processes (15) and found in many central and peripheral neural pathways. SP is released from fifth cranial nerve, the trigeminal, which is part of trigeminal system that is explained below.

\section{TRIGEMINAL SYSTEM}

Trigeminal system is highly established and well-studied system in mammals and birds (16). SP immunoreactivity (SP-IR) has been observed in trigeminal (17) and dorsal root ganglia (DRG) (18). Main feature of this system is the presence of two distinct primary afferent neuronal groups: trigeminal ganglion (TG) and mesencephalic trigeminal nucleus (MTN). Cell bodies of these primary afferent neurons are present in TG (19), and few lie in MTN. MTN is involved mainly in proprioception (mainly orofacial musculature) (20). TG dorsomedial part is involved in nociception, thermoreception, and proprioception while its ventrolateral part is involved in mechanoreception (21). Signals from the trigeminal system are transmitted by second order neurons in brainstem to different regions of CNS pain centers (22). The processes in the middle of ganglion end up on various groups of second order neurons, which convey their signals to the somatosensory cortex via thalamus (23) (Figure 1).

\section{TRIGEMINAL GANGLION}

Trigeminal ganglion is accumulation of pseudounipolar neurons (24) and consists of neurons and their fibers. TG is a cranial analog of DRG in PNS (21). Activation of TG nerves plays a central role in most forms of orofacial pain (25). Many neurotransmitters and their receptors are localized in different subpopulations of TG neurons (21). TG neurons supply innervations mostly to the mechanoreceptors, thermoreceptors, and nociceptors in orofacial region (16). Glial cells also known as satellite cells (26) completely enclose the neuronal somata of TG neurons, and thus they have no synaptic contacts (27).

Based on their appearance, ganglion cells are classified as follows: large light (A) and small dark (B) cells (28). Large light A cells produce thick myelinated fibers while the thin $C$ fibers (both myelinated and unmyelinated) are originated from small dark B cells (29). Two primary afferent neuron subpopulations are noticed in TG: small- and medium-sized neurons with small somata, including glutamate, somatostatin, SP, neurokinin A, CGRP, cholecystokinin, vasoactive intestinal peptide, and galanin, and larger sized neurons that are relatively less and include neuropeptide $Y$ and peptide 19. Presence of SP in small diameter primary afferent fibers and in nociceptive centers of brain gives us an idea of its nociceptive role (30).

\section{TRIGEMINAL NERVE (TrN)}

Trigeminal ganglion provides somatosensory innervations of face and oral cavity through $\operatorname{TrN}$ (31) (Figure 2). It has three branches: V1 and V2 are purely sensory while V3 has both sensory and motor functions. V1 innervates forehead, upper eyelid, cornea, conjunctiva, mucosa of frontal ethmoid and sphenoid sinuses, and dorsum of nose. V2 innervates upper lip, lateral portions of nose, parts of oral cavity, mucosa of nasal cavity, maxillary sinus, upper jaw, and roof of mouth and upper dental arch while V3 innervates lower lip, chin, cheek, lower teeth, gingival, mucosa of lower jaw, floor of mouth, and anterior twothirds of tongue (25).

\section{NEUROKININ RECEPTORS}

Tachykinin receptors also known as neurokinins (NK) are G protein-coupled receptors, localized in the nucleus of the solitary

\begin{tabular}{|l|l|l|l|}
\hline \multicolumn{1}{|c|}{ first order neurons } \\
$\begin{array}{l}\text { Peripheral } \\
\text { nociceptors } \\
\text { (Orofacial pain/ } \\
\text { temperature }\end{array}$
\end{tabular}




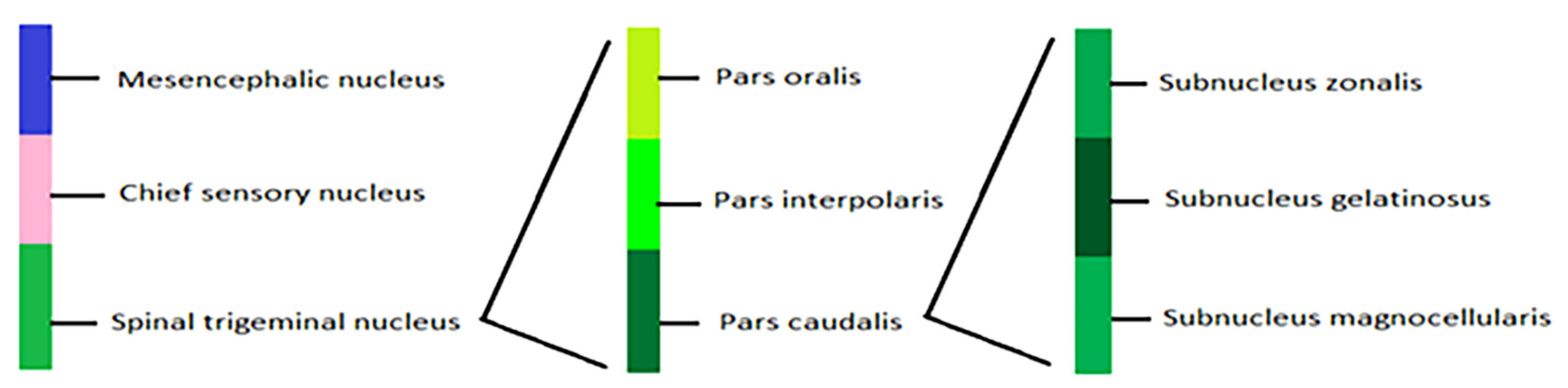

FIGURE 2 | Graphical representation of trigeminal nerve nucleus.

tract, which is known to be involved in the rhythmic control (32). There are three NK receptors (1R-3R). Functional activities of SP are initiated after binding to the neurokinin 1 (NK-1R), which is a transmembrane protein (33). Upon binding, a chain of signaling events is activated by the internalization of SP-NK-1R complex (34), which stimulates the second messenger phospholipase C resulting in the production of inositol 1,4,5-trisphosphate (IP3) and diacylglycerol (DAG) (35). Calcium is released intracellularly as a result of stimulation of endoplasmic reticulum by IP3, and protein kinase $\mathrm{C}$ is activated by DAG (36).

These neurokinin receptors are present within the cardiorespiratory regulatory control centers and in the phrenic nucleus, which controls the diaphragm and mediates the respiratory responses to SP. Prototype TK, SP, was reported to stimulate the respiratory rhythm in wild-type mice, in the in vitro brainstem-spinal cord preparation but not in the NK-1R knockout (NK-1R-/-) mice (37). The study of in vitro brainstem preparations revealed that NK-Rs have a vital role in the regulation of respiratory control and lung burst activity during the development of bullfrog from tadpole to adult stage (38). Role of SP has been implicated in the development of plasticity of respiratory system and the regulation of respiratory rhythm. A functional SP-ergic system is necessary for the generation of sufficient ventilatory responses to hypoxia in newborn mice and during early maturation (39). Under increasing hypoxia, SP manifests as natural anti-hypoxant and is not only involved in nociception mechanisms but also in brain adaptation to oxygen deficiency (40). SP-ergic system was found to be more active in regulating the respiratory responses during the early postnatal period in neonatal rat brainstem-spinal cord preparation (41) and medullary slice preparations of newborn mice (42). But surprisingly, SP was not found to control ventilatory rhythm generation in fetal rats, and it was hypothesized that, may be, SP does not modulate the generation of respiratory responses before birth and affects the phrenic motoneurons only after birth (43).

\section{ROLE OF SP/NK-1R IN REGULATION OF RESPIRATORY RHYTHM}

Neuromodulator SP causes dilation of vessels, contraction of smooth muscles in the respiratory system, increased action potential in neurons, an increase in vascular flow, and production of saliva (44). In humans, NK-1R is involved in causing bronchoconstriction (45). NK-1Rs mediate increases in secretion of mucous glands in human trachea (46). SP-IR was observed to be potentiated in a study conducted on the bronchoalveolar lavage fluid (47) and sputum samples (48) from asthmatic patients. NK-1R mRNA expression was also higher in asthmatic lung tissue when compared to non-asthmatic (49). Elevated levels of SP and PPT-A mRNA were observed in the nodose ganglia of ovalbumin-sensitized guinea pigs (50) with increased neurogenic inflammation and bronchoconstriction produced by NK-1R (51). It suggests that $\mathrm{SP} / \mathrm{NK}-1 \mathrm{R}$ and neurogenic immunoreactivity are critical for the progression of airway hyperresponsiveness (AHR) (52), and NK-1R antagonists attenuated the AHR and plasma extravasation in animal models in vivo (51). The underlying mechanism in causing AHR may be the airway inflammation and interaction of SP and CGRP (calcitonin gene-related peptide) (53). Mice deficient in NK-1Rs show reduced IgG-mediated lung injury and neutrophil infiltration as compared to the control group (54). SP is present in bronchopulmonary C fibers (PCFs) and defend the lungs against injury from inhaled agents by a CNS reflex consisting of apnea, cough, bronchoconstriction, hypotension, bradycardia (55), secretion from seromucous glands, release of mediators (including prostaglandins and NO) from the airway epithelium (56), and bronchorelaxation (57). SP synthesis in vagal airway $\mathrm{C}$ fibers may be enhanced in pathological conditions such as allergic asthma and chronic bronchitis and may be responsible for some of the associated respiratory symptoms stated above (55). SP produces bronchoconstriction and lung resistance in cynomolgus monkeys (58) and sheep (59) via NK-1 receptors, and this effect is more pronounced when they are given by the intravenous route.

\section{EVIDENCE OF INVOLVEMENT OF SPINAL TRIGEMINAL NUCLEUS IN RESPIRATORY RHYTHMIC CONTROL}

Few earlier studies with small sample size have been performed in relation to SP expression in brainstems of SIDS (60-63). Our group (11) defined localization, morphology, and functional aspects of $\operatorname{TrN}$ in different developmental stages of human brain 
development for the first time in cases of sudden perinatal death victims. This study revealed that fetuses in control group had no well-defined $\operatorname{TrN}$ as there was either weak or no SP expression, while in medulla oblongata sections from control infants, a well-defined $\operatorname{TrN}$ with recognizable tract was observed. While SP expression was depleted in SIDS victim brainstems showing TrN hypoplasia and enhanced in SUID victims. Density of SP varied from very low in fetuses to very high in infants, which points out to the functional requirement of $\operatorname{TrN}$ in postnatal period of human life. $\operatorname{TrN}$ development is enhanced in late developmental stages of brain, which was identified by enhanced SP expression. Recently, trigeminocardiac reflex has been suggested as an underlying mechanism for the pathogenesis of SIDS (7).

I have also reported in a previous computational study that $\mathrm{SP} / \mathrm{NK}-1 \mathrm{R}$ has small protein interaction network, its gene is singleton, providing a possibility that it may be involved in some extremely crucial activities of human developmental phases, and any perturbation in terms of mutations in the gene can lead to lethal outcomes including sudden death (64). Similarly, in another study, I along with my colleagues observed higher expression of SP in oral cancer patients from Pakistani population. This expression was directly proportional to the grade of cancer and poor prognosis. This study also confirms the involvement of SP in nociceptive stimuli in orofacial region (65). In our previous study (11), we detected SP expression in medulla oblongata and spinal cord from early stages of human brainstem development, exclusively in the spinal TrN. This phenomenon exhibits that SP is highly specific and localized in human brain. Very few studies focus on the $\operatorname{TrN}$ in humans $(66,67)$. As spinal trigeminal nucleus and its tract have no definite boundaries, it is difficult to identify it. Nevertheless, it can be recognized by labeling it with SP, which is its main neurotransmitter (11). In experimental murine studies, $\operatorname{TrN}$ was observed to be involved in rhythmic autonomic behaviors including breathing $(68,69)$. These studies also suggested an essential role of $\mathrm{TrN}$ in controlling respiratory rhythm, and its activity was observed to be altered in respiratory disorders $(70,71)$.

Observations from a recent study by Hayashi and Sakuma (72) are also concordant with our observations and findings that SP

\section{REFERENCES}

1. Willinger M, James LS, Catz C. Defining the sudden infant death syndrome (SIDS): deliberations of an expert panel convened by the National Institute of Child Health and Human Development. Pediatr Pathol (1991) 11(5):677-84. doi:10.3109/15513819109065465

2. Lavezzi AM. A new theory to explain the underlying pathogenetic mechanism of sudden infant death syndrome. Front Neurol (2015) 6:220. doi:10.3389/fneur.2015.00220

3. Bergman AB, Beckwith JB, Ray CG. Sudden infant death syndrome. Proceedings of the Second International Conference on Causes of Sudden Death in Infants. Seattle: University of Washington Press (1970).

4. Filiano JJ, Kinney HC. A perspective on neuropathologic findings in victims of the sudden infant death syndrome: the triple-risk model. Biol Neonate (1994) 65(3-4):194-7. doi:10.1159/000244052

5. Machaalani R, Waters KA. Neurochemical abnormalities in the brainstem of the sudden infant death syndrome (SIDS). Paediatr Respir Rev (2014) 15(4):293-300. doi:10.1016/j.prrv.2014.09.008

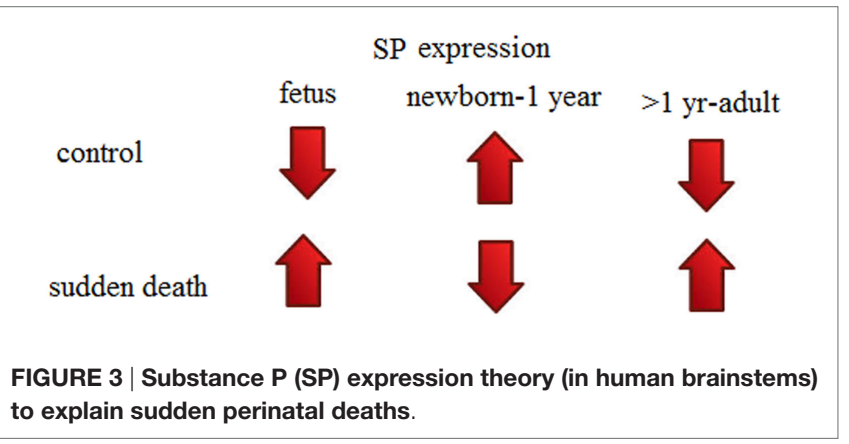

expression was elevated in seven out of eight victims of sudden unexplained deaths. A previous study also suggested that SP containing cells in human TG is variable in different age groups; $24 \%$ in neonates while $17 \%$ in adults (73). Study of Hayashi and Sakuma (72) shows expression of SP in brainstem of children and adults as compared to our study, which reported SP expression in SIDS and SUID. If we summarize the findings of both studies and compare them with our study also, we reach to conclusion that SP expression in brainstems is negligible in fetus, enhanced in neonates while decreased in children and adults in controls. While if vice versa it leads to sudden deaths (Figure 3).

\section{CONCLUSION}

Studies suggest an important role of SP/NK-1R and trigeminal system during the critical neurodevelopmental periods in which brain is preparing to deal with vital autonomic functions such as breathing, required for the start of new life after birth. Trigeminal nucleus hypoplasia and variations in expression of SP in sudden perinatal death victims as compared to controls provide a possibility of revealing one of the underlying mechanisms in its pathophysiology.

\section{AUTHOR CONTRIBUTIONS}

RM has designed, planned, written, and contributed to this review manuscript.

6. Ottaviani G. Defining sudden infant death and sudden intrauterine unexpected death syndromes with regard to anatomo-pathological examination. Front Pediatr (2016) 4:103. doi:10.3389/fped.2016.00103

7. Singh GP, Chowdhury T, Bindu B, Schaller B. Sudden infant death syndrome - role of trigeminocardiac reflex: a review. Front Neurol (2016) 7:221. doi:10.3389/fneur.2016.00221

8. Lavezzi AM, Ottaviani G, Ballabio G, Rossi L, Matturri L. Preliminary study on the cytoarchitecture of the human parabrachial/Kolliker-fuse complex, with reference to sudden infant death syndrome and sudden intrauterine unexplained death. Pediatr Dev Pathol (2004) 7(2):171-9. doi:10.1007/ s10024-003-1011-7

9. Lavezzi AM, Ottaviani G, Matturri L. Adverse effects of prenatal tobacco smoke exposure on biological parameters of the developing brainstem. Neurobiol Dis (2005) 20(2):601-7. doi:10.1016/j.nbd.2005.04.015

10. Lavezzi AM, Corna M, Matturri L, Santoro F. Neuropathology of the Guillain-Mollaret triangle (dentato-rubro-olivary network) in sudden unexplained perinatal death and SIDS. Open Neurol J (2009) 3:48-53. doi:10.2174/1874205X00903010048 
11. Lavezzi AM, Mehboob R, Matturri L. Developmental alterations of the spinal trigeminal nucleus disclosed by substance $\mathrm{P}$ immunohistochemistry in fetal and infant sudden unexplained deaths. Neuropathology (2011) 31(4):405-13. doi:10.1111/j.1440-1789.2010.01190.x

12. Felderbauer P, Bulut K, Hoeck K, Deters S, Schmidt WE, Hoffmann P. Substance $\mathrm{P}$ induces intestinal wound healing via fibroblasts - evidence for a TGF-beta-dependent effect. Int J Colorectal Dis (2007) 22(12):1475-80. doi:10.1007/s00384-007-0321-z

13. Pernow B. Substance P. Pharmacol Rev (1983) 35(2):85-141.

14. Severini C, Improta G, Falconieri-Erspamer G, Salvadori S, Erspamer V. The tachykinin peptide family. Pharmacol Rev (2002) 54(2):285-322. doi:10.1124/pr.54.2.285

15. Ebner K, Singewald N. The role of substance $P$ in stress and anxiety responses. Amino Acids (2006) 31(3):251-72. doi:10.1007/s00726-006-0335-9

16. Davies AM. The trigeminal system: an advantageous experimental model for studying neuronal development. Development (1988) 103(Suppl):175-83.

17. Lee Y, Kawai Y, Shiosaka S, Takami K, Kiyama H, Hillyard CJ, et al. Coexistence of calcitonin gene-related peptide and substance P-like peptide in single cells of the trigeminal ganglion of the rat: immunohistochemical analysis. Brain Res (1985) 330(1):194-6. doi:10.1016/00068993(85)90027-7

18. Gibbins IL, Furness JB, Costa M. Pathway-specific patterns of the co-existence of substance $\mathrm{P}$, calcitonin gene-related peptide, cholecystokinin and dynorphin in neurons of the dorsal root ganglia of the guinea-pig. Cell Tissue Res (1987) 248(2):417-37. doi:10.1007/BF00218210

19. Lazarov NE. The mesencephalic trigeminal nucleus in the cat. Adv Anat Embryol Cell Biol (2000) 153(iii-xiv):1-103. doi:10.1007/978-3-642-57176-3

20. Nagy JI, Buss M, Daddona PE. On the innervation of trigeminal mesencephalic primary afferent neurons by adenosine deaminase-containing projections from the hypothalamus in the rat. Neuroscience (1986) 17(1):141-56. doi:10.1016/0306-4522(86)90232-0

21. Lazarov NE. Comparative analysis of the chemical neuroanatomy of the mammalian trigeminal ganglion and mesencephalic trigeminal nucleus. Prog Neurobiol (2002) 66(1):19-59. doi:10.1016/S0301-0082(01)00021-1

22. Eftekhari S, Salvatore CA, Calamari A, Kane SA, Tajti J, Edvinsson L. Differential distribution of calcitonin gene-related peptide and its receptor components in the human trigeminal ganglion. Neuroscience (2010) 169(2):683-96. doi:10.1016/j.neuroscience.2010.05.016

23. Pfaller K, Arvidsson J. Central distribution of trigeminal and upper cervical primary afferents in the rat studied by anterograde transport of horseradish peroxidase conjugated to wheat germ agglutinin. J Comp Neurol (1988) 268(1):91-108. doi:10.1002/cne.902680110

24. Krastev D, Paloff A, Hinova D, Apostolov A, Ovcharoff W, Krastev N. [Ganglion trigeminale]. Khirurgiia (2008) 3:55-8. Article in Bulgarian.

25. Takemura M, Sugiyo S, Moritani M, Kobayashi M, Yonehara N. Mechanisms of orofacial pain control in the central nervous system. Arch Histol Cytol (2006) 69(2):79-100. doi:10.1679/aohc.69.79

26. Pannese E. The satellite cells of the sensory ganglia. Adv Anat Embryol Cell Biol (1981) 65:1-111. doi:10.1007/978-3-642-67750-2_1

27. Lieberman AR. Sensory ganglia. In: Landon DN, editor. The Peripheral Nerve. London: Chapman and Halled (1976). p. 188-278.

28. Gaik GC, Farbman AI. The chicken trigeminal ganglion. I. An anatomical analysis of the neuron types in the adult. J Morphol (1973) 141(1):43-55. doi:10.1002/jmor.1051410103

29. Scharf JH, Rowe CP. [Distribution of carbohydrates and some enzymes in the semilunar ganglion of cattle]. Acta Histochem (1958) 5(5-8):129-45.

30. Levine JD, Fields HL, Basbaum AI. Peptides and the primary afferent nociceptor. J Neurosci (1993) 13(6):2273-86.

31. Voogd J, Glickstein M. The anatomy of the cerebellum. Trends Neurosci (1998) 21(9):370-5. doi:10.1016/S0166-2236(98)01318-6

32. Mazzone SB, Geraghty DP. Respiratory actions of tachykinins in the nucleus of the solitary tract: effect of neonatal capsaicin pretreatment. Br J Pharmacol (2000) 129(6):1132-9. doi:10.1038/sj.bjp.0703173

33. Helke CJ, Krause JE, Mantyh PW, Couture R, Bannon MJ. Diversity in mammalian tachykinin peptidergic neurons: multiple peptides, receptors, and regulatory mechanisms. FASEB J (1990) 4(6):1606-15.

34. Quartara L, Maggi CA. The tachykinin NK1 receptor. Part I: ligands and mechanisms of cellular activation. Neuropeptides (1997) 31(6):537-63. doi:10.1016/S0143-4179(97)90001-9
35. Ramkissoon SH, Patel HJ, Taborga M, Rameshwar P. G protein-coupled receptors in haematopoietic disruption. Expert Opin Biol Ther (2006) 6(2):109-20. doi:10.1517/14712598.6.2.109

36. Radhakrishnan V, Yashpal K, Hui-Chan CW, Henry JL. Implication of a nitric oxide synthase mechanism in the action of substance P: L-NAME blocks thermal hyperalgesia induced by endogenous and exogenous substance $\mathrm{P}$ in the rat. Eur J Neurosci (1995) 7(9):1920-5. doi:10.1111/j.1460-9568.1995. tb00714.x

37. Ptak K, Hunt SP, Monteau R. Substance P and central respiratory activity: a comparative in vitro study in NK1 receptor knockout and wild-type mice. Pflugers Arch (2000) 440(3):446-51. doi:10.1007/s004240000300

38. Chen AK, Hedrick MS. Role of glutamate and substance P in the amphibian respiratory network during development. Respir Physiol Neurobiol (2008) 162(1):24-31. doi:10.1016/j.resp.2008.03.010

39. Berner J, Shvarev Y, Lagercrantz H, Bilkei-Gorzo A, Hokfelt T, Wickstrom R. Altered respiratory pattern and hypoxic response in transgenic newborn mice lacking the tachykinin-1 gene. J Appl Physiol (1985) (2007) 103(2):552-9. doi:10.1152/japplphysiol.01389.2006

40. Vlasova IG, Torshin VI. [Antihypoxic properties of opiates and substance P]. Patol Fiziol Eksp Ter (2001) 2:13-5. Article in Russian.

41. Shvarev YN, Lagercrantz H. Early postnatal changes in respiratory activity in rat in vitro and modulatory effects of substance P. Eur J Neurosci (2006) 24(8):2253-63. doi:10.1111/j.1460-9568.2006.05087.x

42. Yasuda K, Robinson DM, Selvaratnam SR, Walsh CW, McMorland AJ, Funk GD. Modulation of hypoglossal motoneuron excitability by NK1 receptor activation in neonatal mice in vitro. J Physiol (2001) 534(Pt 2):447-64. doi:10.1111/j.1469-7793.2001.00447.x

43. Ptak K, Di Pasquale E, Monteau R. Substance P and central respiratory activity: a comparative in vitro study on foetal and newborn rat. Brain Res Dev Brain Res (1999) 114(2):217-27. doi:10.1016/S0165-3806(99)00044-9

44. Koch BL, Edvinsson AA, Koskinen LO. Inhalation of substance $\mathrm{P}$ and thiorphan: acute toxicity and effects on respiration in conscious guinea pigs. J Appl Toxicol (1999) 19(1):19-23. doi:10.1002/ (SICI)1099-1263(199901/02)19:1<19::AID-JAT533>3.0.CO;2-R

45. Naline E, Molimard M, Regoli D, Emonds-Alt X, Bellamy JF, Advenier C. Evidence for functional tachykinin NK1 receptors on human isolated small bronchi. Am J Physiol (1996) 271(5 Pt 1):L763-7.

46. Rogers DF, Aursudkij B, Barnes PJ. Effects of tachykinins on mucus secretion in human bronchi in vitro. Eur J Pharmacol (1989) 174(2-3):283-6. doi:10.1016/0014-2999(89)90322-1

47. Nieber K, Baumgarten CR, Rathsack R, Furkert J, Oehme P, Kunkel G. Substance $\mathrm{P}$ and beta-endorphin-like immunoreactivity in lavage fluids of subjects with and without allergic asthma. J Allergy Clin Immunol (1992) 90(4 Pt 1):646-52. doi:10.1016/0091-6749(92)90138-R

48. Tomaki M, Ichinose M, Miura M, Hirayama Y, Yamauchi H, Nakajima N, et al. Elevated substance $\mathrm{P}$ content in induced sputum from patients with asthma and patients with chronic bronchitis. Am J Respir Crit Care Med (1995) 151(3 Pt 1):613-7. doi:10.1164/ajrccm.151.3.7533601

49. Adcock IM, Peters M, Gelder C, Shirasaki H, Brown CR, Barnes PJ. Increased tachykinin receptor gene expression in asthmatic lung and its modulation by steroids. J Mol Endocrinol (1993) 11(1):1-7. doi:10.1677/jme. 0.0110001

50. Fischer A, McGregor GP, Saria A, Philippin B, Kummer W. Induction of tachykinin gene and peptide expression in guinea pig nodose primary afferent neurons by allergic airway inflammation. J Clin Invest (1996) 98(10):2284-91. doi:10.1172/JCI119039

51. Harrison S, Geppetti P. Substance p. Int J Biochem Cell Biol (2001) 33(6):555-76. doi:10.1016/S1357-2725(01)00031-0

52. Bertrand C, Geppetti P. Tachykinin and kinin receptor antagonists: therapeutic perspectives in allergic airway disease. Trends Pharmacol Sci (1996) 17(7):255-9. doi:10.1016/0165-6147(96)10027-4

53. Wu H, Guan C, Qin X, Xiang Y, Qi M, Luo Z, et al. Upregulation of substance $\mathrm{P}$ receptor expression by calcitonin gene-related peptide, a possible cooperative action of two neuropeptides involved in airway inflammation. Pulm Pharmacol Ther (2007) 20(5):513-24. doi:10.1016/j.pupt. 2006.04.002

54. Bozic CR, Lu B, Hopken UE, Gerard C, Gerard NP. Neurogenic amplification of immune complex inflammation. Science (1996) 273(5282):1722-5 doi:10.1126/science.273.5282.1722 
55. Mutoh T, Bonham AC, Joad JP. Substance P in the nucleus of the solitary tract augments bronchopulmonary C fiber reflex output. Am J Physiol Regul Integr Comp Physiol (2000) 279(4):R1215-23.

56. Geppetti P, Bertrand C, Bacci E, Huber O, Nadel JA. Characterization of tachykinin receptors in ferret trachea by peptide agonists and nonpeptide antagonists. Am J Physiol (1993) 265(2 Pt 1):L164-9.

57. Figini M, Emanueli C, Bertrand C, Javdan P, Geppetti P. Evidence that tachykinins relax the guinea-pig trachea via nitric oxide release and by stimulation of a septide-insensitive NK1 receptor. Br J Pharmacol (1996) 117(6):1270-6. doi:10.1111/j.1476-5381.1996.tb16725.x

58. Mauser PJ, Skeans S, Ritacco G, Fernandez X, House A, Chapman RW. Effect of tachykinins on airway function in cynomolgus monkeys. Pulm Pharmacol Ther (2001) 14(2):121-7. doi:10.1006/pupt.2001.0278

59. Rice AJ, Reynolds PN, Reynolds AM, Holmes MD, Scicchitano R. Tachykinin-induced bronchoconstriction in sheep is NK-1 receptor mediated and exhibits tachyphylaxis. Respirology (2001) 6(2):113-23. doi:10.1046/j.1440-1843.2001.00315.x

60. Obonai T, Takashima S, Becker LE, Asanuma M, Mizuta R, Horie H, et al. Relationship of substance $\mathrm{P}$ and gliosis in medulla oblongata in neonatal sudden infant death syndrome. Pediatr Neurol (1996) 15(3):189-92. doi:10.1016/S0887-8994(96)00217-2

61. Ozawa Y, Takashima S. Developmental neurotransmitter pathology in the brainstem of sudden infant death syndrome: a review and sleep position. Forensic Sci Int (2002) 130(Suppl):S53-9. doi:10.1016/ S0379-0738(02)00139-1

62. Yamanouchi H, Takashima S, Becker LE. Correlation of astrogliosis and substance $\mathrm{P}$ immunoreactivity in the brainstem of victims of sudden infant death syndrome. Neuropediatrics (1993) 24(4):200-3. doi:10.1055/ s-2008-1071539

63. Sawaguchi T, Ozawa Y, Patricia F, Kadhim H, Groswasser J, Sottiaux M, et al. Substance $\mathrm{P}$ in the midbrains of SIDS victims and its correlation with sleep apnea. Early Hum Dev (2003) 75(Suppl):S51-9. doi:10.1016/j. earlhumdev.2003.08.011

64. Mehboob R, Shahzad SA, Hashmi AM, Ahmad FJ. Vertebrate specific oncogenic TAC1 has unconventional networking properties. Healthmed (2014) 8(7):843.
65. Mehboob R, Tanvir I, Warraich RA, Perveen S, Yasmeen S, Ahmad FJ. Role of neurotransmitter Substance P in progression of oral squamous cell carcinoma. Pathol Res Pract (2015) 211(3):203-7. doi:10.1016/j.prp.2014.09.016

66. Rusu MC. The spinal trigeminal nucleus - considerations on the structure of the nucleus caudalis. Folia Morphol (2004) 63(3):325-8.

67. Dallel R, Villanueva L, Woda A, Voisin D. [Neurobiology of trigeminal pain]. Med Sci (Paris) (2003) 19(5):567-74. doi:10.1051/medsci/2003195567

68. Goldberg LJ, Chandler SH. Central mechanisms of rhythmic trigeminal activity. In: Taylor A, editor. Neurophysiology of Jaws and Teeth. London: Macmillan (1990). p. 268-321.

69. Lund JP, Kolta A, Westberg KG, Scott G. Brainstem mechanisms underlying feeding behaviors. Curr Opin Neurobiol (1998) 8(6):718-24. doi:10.1016/ S0959-4388(98)80113-X

70. Chandler SH, Chase MH, Nakamura Y. Intracellular analysis of synaptic mechanisms controlling trigeminal motoneuron activity during sleep and wakefulness. J Neurophysiol (1980) 44(2):359-71.

71. Chamberlin NL, Saper CB. A brainstem network mediating apneic reflexes in the rat. J Neurosci (1998) 18(15):6048-56.

72. Hayashi M, Sakuma H. Immunohistochemical analysis of brainstem lesions in the autopsy cases with severe motor and intellectual disabilities showing sudden unexplained death. Front Neurol (2016) 7:93. doi:10.3389/ fneur.2016.00093

73. Del Fiacco M, Quartu M, Floris A, Diaz G. Substance P-like immunoreactivity in the human trigeminal ganglion. Neurosci Lett (1990) 110(1-2):16-21. doi:10.1016/0304-3940(90)90780-D

Conflict of Interest Statement: The author declares that the research was conducted in the absence of any commercial or financial relationships that could be construed as a potential conflict of interest.

Copyright (c) 2017 Mehboob. This is an open-access article distributed under the terms of the Creative Commons Attribution License (CC BY). The use, distribution or reproduction in other forums is permitted, provided the original author(s) or licensor are credited and that the original publication in this journal is cited, in accordance with accepted academic practice. No use, distribution or reproduction is permitted which does not comply with these terms. 